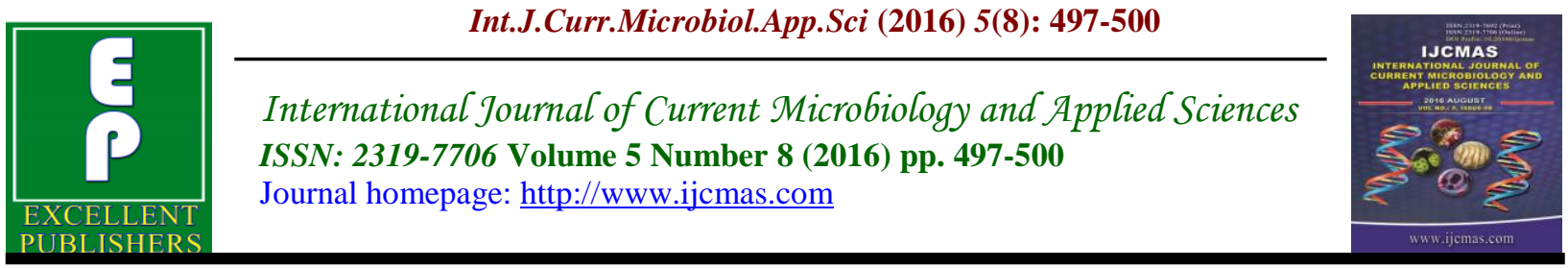

Original Research Article

http://dx.doi.org/10.20546/ijcmas.2016.508.053

\title{
Antibacterial Activity of Petals
}

\author{
B.S. Anuradha* \\ Department of Microbiology, Chaitanya Postgraduate College Hanamkonda, Telangana, India \\ *Corresponding author
}

\begin{tabular}{|c|c|}
\hline & A B S T R A C T \\
\hline Keywords & \multirow{4}{*}{$\begin{array}{l}\text { The present work study involves extraction of active ingredients from petals of } \\
\text { Shoe flower (Hibiscus rosa sinensis), Chrysanthemum (Chrysanthemum indicum.), } \\
\text { Ixora (Ixora coccinea), Jasmine (Jasminums ambac), Rose (Rosaindica), } \\
\text { Catharanthus (Catharanthusroseus Pomegranate (Punica granatum) and to studied } \\
\text { the antimicrobial activity on common human pathogens like Staphylococci aureus } \\
\text { and Ecoli by agar well diffusion method. It is inferred that the crude extract of the } \\
\text { petals of C.roseus, Jasmine, Ixora have satisfactory activity against Staphylococci } \\
\text { aureus and E. coli, expected Chrysanthemum has satisfactory antimicrobial activity } \\
\text { against Staphylococci aureus but not against E coli. The present findings suggest } \\
\text { that the petals of C.roseus can be used as antibacterial agent in new drugs for } \\
\text { therapv against E.coli and Staphvlococci aureus. }\end{array}$} \\
\hline $\begin{array}{l}\text { Shoe flower } \\
\text { Chrysanthemum, } \\
\text { Ixora, } \\
\text { Jasmine, Rose. }\end{array}$ & \\
\hline Article Info & \\
\hline $\begin{array}{l}\text { Accepted: } \\
\text { 23 July } 2016 \\
\text { Available Online: } \\
10 \text { August } 2016\end{array}$ & \\
\hline
\end{tabular}

\section{Introduction}

Ever since the origin of mankind, a silent battle is in progress with the microorganism, each developing newer strategies to fight against each other. The prominent strategy in developing newer antimicrobial compounds started its leaps and bounds from the $20^{\text {th }}$ century. These are also called as magic bullets as they selectively find the pathogen and destroy the pathogen but do not harm the host. Nature has been a source of medicinal agents for thousands of years and an impressive number of modern drugs have been isolated from natural sources, many based on their use in traditional medicine Higher plants, as sources of medicinal compounds, have continued to play a dominant role in the maintenance of human health since ancient times (Farombi, 2003). Natural products play an important role in drug development programs in the pharmaceutical industry (Baker et al., 1995). There are number of practical difficulties and bottle neck problems associated with the isolation and purification of antimicrobial compounds from these sources. To overcome this problem new novel antimicrobial compounds have to be discovered. Various plants have been screened all around the world every year to find the antimicrobial activity. Several studies reveal the presence of compounds with antimicrobial properties in various plant parts (Ieven et al., 1979; Shanmuga Priya et al., 2002). While the information on 
antimicrobial activity of plant flowers and especially petals were scanty, the petals provide physical protection to the reproductive organs can be expected to synthesize potent bioactive compounds (Sridevi et al., 2011). Interestingly symptoms of most plant diseases of bacterial or fungal origin have been reported mostly on leaves, stem, root and seldom on petals (Perez et al., 1990). The effects of plant extracts on bacteria have been studied by a very large number of researchers in different parts of the world. Much work has been done on ethno medicinal plants in India (Lovelli et al., 1993; Tumane et al., 2000; Karuppuswamy et al., 2002; Reddy et al., 2001; Vijayalaxmi et al., 2011). It has been suggested that aqueous and ethanolic extracts from plants used in allopathic medicine are potential sources of antiviral, antitumoral and antimicrobial agents. The selection of crude plant extracts for screening programs has the potential of being more successful in initial steps than the screening of pure compounds isolated from natural products (Reddy et al., 2011; Vijayalaxmi et al., 2011; Parmar et al., 1978). Plant based antimicrobial s represent a vast untapped source for medicine and has enormous therapeutic potentials.

Hence the antimicrobial activity of Shoe flower (Hibiscus rosa sinensis), Chrysanthemum (Chrysanthemum indicum), Ixora (Ixora coccinea), Jasmine (Jasminum sambac), Rose (Rosa indica), Catharanthus (Catharanthus roseus), Pomegranate (Punica granatum) plant flower petals has been investigated in the present study.

\section{Materials and Methods}

\section{Collection of floral parts and preparation of extracts}

The flower petals of Hibiscus, Chrysanthemum, Ixora, Jasmine,
Catharanthus, and Pomegranate were collected from various places in Hanamkonda Warangal A.P India.

The petals were surface sterilized with $0.1 \%$ Mercuric Chloride for 10 seconds. And washed with sterile distilled water for three successive times. The petals were dried in a drier and then crushed in mortar and pestle and aqueous extracts were prepared with sterile distilled water and filtered through Millipore filter.

\section{Bacterial strains}

Antibacterial activity of crude extracts of plant floral extracts were tested against Staphylococci aureus and $E$ coli. The bacterial cultures were obtained from IMTECH (Chandigarh, India) within $24 \mathrm{~h}$ cultures were taken and inoculated in Nutrient agar medium. (Peptone $(5 \mathrm{~g})$, Beef extract (3g), $\mathrm{NaCl}(5 \mathrm{~g})$, distilled water $1000 \mathrm{ml})$

\section{Antibacterial activity}

Antibacterial activity of plant floral extracts was determined by Agar-Agar well diffusion method (8) .Nutrient agar plats were prepared by pour plate method. To the molten sterile NAM $\left(40^{\circ}-45^{\circ} \mathrm{C}\right), 0.1 \mathrm{~mL}$ of growth culture of the concerned test organism was mixed thoroughly and poured into sterile petriplate and allowed to solidify.

Wells of $3 \mathrm{~mm}$ size were made with sterile cork borer and $50 \mu \mathrm{l}$ of the floral petal filtrate was poured into these wells. The plates were incubated for $24 \mathrm{~h}$ at $37^{\circ} \mathrm{C}$. After the stipulated time the plates were observed for formation of inhibition zones. The diameter of the inhibition zones were measured using an antibiotic zone scale. The medium containing antibiotic streptomycin at a concentration of $10 \mu \mathrm{g} / \mathrm{ml}$ was used as control. 


\section{Results and Discussion}

The antibacterial activity of crude extract of petals from various plants was tested against both Gram +ve (Staphylococci aureus) and Gram -ve $(E$ coli $)$ and the results are shown in the Table 1. All the petals of the plants showed antimicrobial activity. Among the seven types of plant petals, 6 showed antimicrobial activity against both Staphylococci and E, coli, where as Chrysanthemum did not show any antimicrobial activity against $E$ coli. The petal extracts of Pomegranate showed maximum antimicrobial activity against Staphylococci aureus $(3 \mathrm{~mm})$ followed by the petal extracts of Hibiscus, Catharanthus and Ixora. (2mm).

Table.1 Anti microbial activity of various petals on Staphylococcus aureus and E.coli

\begin{tabular}{llcc}
\hline S. No & Name of the plant & Zone of Inhibition $(\mathbf{m m})$ & \\
\cline { 3 - 4 } & & Staphylococcus aureus & E. coli \\
\cline { 3 - 4 } & Hibiscus rosa sinesis & 2 & 1 \\
2 & Chrysanthemum indicum & 1 & 0 \\
3 & Rosa indica & 1 & 3 \\
4 & Ixora coccinea & 2 & 1 \\
5 & Catharanthes roseus & 3 & 0.5 \\
6 & Punica granatum & 0.5 & 2 \\
7 & Jasminum sambac & 6 & 1 \\
8 & Streptomycin (Standard) & 6 \\
\hline
\end{tabular}

In conclusion, the results revealed that crude extracts which are antimicrobial in nature. These antimicrobial compounds are synthesized by plants in response to microbial infections. The plant can also be further explored for its activity against wide spectrum of microorganisms and can be developed into a powerful antibiotic. The rapidity of this screening procedure by direct testing is a powerful tool to identify the petals of specific plant species as a source of new antibiotics. Flower petals which are mostly used for ornamental purpose or in preparation of aromatic oils can also be used as antimicrobial agents.

\section{References}

Aswal, B.S., Bhakuni, D.S., Goel, A.K., Kar, K., Mehrotra, B.N. 1984. Indian J. Exp. Biol., 22: 487-504.

Baker, J.T., Borris, R.P., Carte, B. 1995. Natural product drug discovery and development: New perspective on international collaboration. J. Nat. Prod., 58: 1325-1357.

Farombi, E.O. 2003. African indigenous plants with chemotherapeutic potentials and biotechnological approach to the production of bioactive prophylactic agents. African J. Biotech., 2: 662-671.

Ieven, M., VandenBerghe, D., Mertens, F., Viletinck, A., Lammens, E. 1979. Plant Media, 36: 311-321.

Karuppuswamy, D., Rajasekharan, K.M., Karmeghan, N. 2002. J. Ecotoxicol. and Environ. Moni., 12: 67-68.

Lovelli, T.H. 1993. Indian J. Medi. Microbial.

Parmar, N.S., Ghosh, M.N. 1978. Indian J. Pharmacol., 10(4): 277-293.

Perez, C., Pauli, M., Bazerque, P., 1990. Acta. Biologia et Medicine Experimentalist, 15: 113-115.

Reddy, P.S., Jamil, K., Madhusudhan, P. et al. 2001. Antibacterial activity of 
isolates from Piper longum and Taxus baccata. Pharmaceutical Biol., 39: 236-238.

Shanmuga Priya, K., Gnanamani, A., Radha Krishanan, N., Mary Babu. 2002. Indian Drugs, 39: 113-116.

Sridevi, A., Vijayalakshmi, M., Narasimha, G. 2011. Antibacterial activity of some higher plant floral petals NPAIJ. 7(4); $168-170$.
Tumane, P.M., Wadher, B.J., Khan Aqueel, Gomashe, A.V., Ingle, A.B. 2000. $J$. Microb. World, 2(2): 47-55.

Vijayalaxmi Devi, Anju, S., and Melchias, G. 2011. In vitro screening of C. Roseus alkaloids for antibacterial activity. The Bioscan, 6(2): 245-248.

\section{How to cite this article:}

Anuradha, B.S., 2016. Antibacterial Activity of Petals. Int.J.Curr.Microbiol.App.Sci. 5(8): 497500. doi: http://dx.doi.org/10.20546/ijcmas.2016.508.053 